\title{
Macro and microscopic structure of the digestive system of Octopus vulgaris From Alexandria water on the Mediterranean Sea
}

\author{
Waheed M Emam*, Abd Alaa M Ibrahim and Tarek Ghareb \\ Zoology Department, Faculty of Science, Ain Shams Univ., Egypt \\ Corresponding Author E-mail: Waheed.emam@yahoo.com
}

\begin{abstract}
The present work deals with the macroscopic and microscopic anatomy of Octopus vulgaris from Alexandria water on the Mediterranean sea. The digestive system is formed of the buccal mass, oesophagus, crop, stomach, caecum, intestine and rectum. The associated glands included the anterior and posterior salivary glands, liver and digestive duct appendages (Pancreas).

In the present study, the structure of the buccal mass, with the upper and lower jaws has been described. Also the radular teeth, which are specific for their morphology and considered of taxonomic evidence for different octopod species, have been described. The oesophagus enters the crop on its right side approximately one third of the way from its anterior end. Musculature and lining epithelium of the two regions have been studied. The stomach is a region where the grinding of food occurs so that its lining epithelium is covered by thick layer of cuticle. The caecum is a coiled organ which lies below the stomach and has primary and secondary leaflet-like structures. Secretory cells are found between the columnar cells which form the lining epithelium. The intestine is a long tube, which is followed by short rectum, and has internal folds with scattered mucous cells between the columnar epithelial cells. The rectum has no mucous cells and its lining epithelium is covered with a thin layer of cuticle. The anterior salivary glands are smaller in size than the posterior ones and have two types of secretory cells like the posterior salivary glands. The digestive gland is a large grayish cigar-shaped organ, consisting of two fused lobes. It has two types of cells, big vaculated cells and small triangular ones. The pancreas lies around the two digestive ducts and forms a small wedge-shaped appendages, each is formed of a single layer of short columnar cells.
\end{abstract}

Key words : Digestive system, cephalopods, Octapoda, anatomy, histology, Octopus vulgaris.

\section{INTRODUCTION}

Octopods represent one of the most common groups of bottom dwellers in different seas and oceans. They are mainly epibenthic animals living in coastal water on the continental shelf. The order Octopoda apparently became distinct from the coleoid basic line in the Middle Triassic ${ }^{(\mathbf{1})}$. Octopods are divided into two suborders; Cirrata, mostly deep-sea pelagic and epibenthic forms which possess cirri along arms and have paddle-shaped fins and Incirrata, moderately deep to shallow-living benthic and epibenthic forms which possess neither cirri or fins. Only the Incirrata are of commercial interest, with some species of octopus supporting among the major fisheries for cephalopods. They are active predators with very diverse food sources ranging from crustaceans to mollusks and fishes. They are considered as one of the marine sources of protein food for man, and other animals. Although by no means 


\section{Waheed M Emam et al.}

they are confined to rocky habitats. Most of our knowledge of the biology of these animals come from species of Octopus living on bottoms of mixed substrata, where the animal typically lives in a "home" or lair from which it makes frequent feeding excursions, to ingest its food and to shelter ${ }^{(2)}$.

Octopus vulgaris has a world-wide distribution in tropical and subtropical temperature waters. It lives in coastal waters and the upper part of the continental shelf. This species is abundant in the Mediterranean sea, the eastern Atlantic and in Japanese waters. It has an economic importance in fisheries of many countries and a potential danger of overfishing ${ }^{(\mathbf{1})}$

Few scattered work have been done on the anatomy and histology of the digestive system of Octopus vulgaris. Mattus ${ }^{(3)}$ studied the fine structure of salivary gland of Elledone cirrosa and $O$. vulgaris. Andrew and Tansey ${ }^{(4)}$ studied the anatomy of the digestive system of $O$. vulgaris.

The present work aims to the macro and microscopic anatomy of the digestive system of Octopus vulgaris from Alexandria water on the Mediterranean Sea. The results represent the basic information necessarry to understand the feeding behavior of this group of cephalopods.

\section{MATERIALS AND METHODS}

Fresh specimens of $O$. vulgaris were obtained from fishermen at Alexandria fish market, apparently which had died in the fishing trawl due to shock after capture, without visible injury. They were preserved in $10 \%$ formalin, and they were dissected in the lab to study the macroscopic anatomy of their digestive system. A Camera Lucida was used to draw the different parts of this system.

For histological studies live specimens were used. They were dissected on the beach directly after their removal from the fishing net where their tissues remain fresh and intact for a considerable time. Meanwhile, the gut shows active and considerable violent peristaltic contractions while dissecting. Samples of tissues were placed into suitable fixatives Bouin's fluid or Zenker's solution for at least 24 hours. After fixations, the tissues were dehydrated in ascending series of ethyl alcohol, cleared in terpineol, embedded in paraffin wax, and were cut into serial sections at 5 $\mu \mathrm{m}$ thick. The sections were deparafinized, hydrated, and stained by various stains, namely Mayer's haematoxylin eosin, toluidine blue and Mallory triple stain.

\section{RESULTS}

The macroscopic anatomy of the digestive system of Octopus vulgaris is shown in (Fig. 1). It is composed of the buccal mass, oesophagus, crop, stomach, caecum, intestine and rectum. The glands attached to this system are the paired anterior and posterior salivary glands, the submandibular glands, and the single digestive gland with the pancreatic or digestive gland appendix.

The buccal mass is a large spherical and yellowish muscular chamber. It lies between the arms and has an upper and a lower circular lips. A pair of powerful dorsal and ventral jaws are found inside the buccal mass (Figs. $2 \& 3$ ). The ventral jaw is overlapping the dorsal one. The posterior and lateral walls of the two jaws are embedded within the mandibular muscles of the lateral buccal palps of the buccal mass. Two submandibular glands lie on the inner lower muscular wall of the buccal mass. The common duct of the posterior salivary glands extends below the radular support (odontophore) and opens anteriorly in the buccal cavity. The radula is also present in the buccal mass. It has long cusps pointing backwards with tricuspes central teeth, unicasped marginal and curved lateral teeth (Fig. 4). 


\section{Macro and microscopic structure of the digestive system of Octopus vulgaris From Alexandria water on the Mediterranean Sea}

The oesophagus is a long, tubular muscular organ, measuring $11 \mathrm{~cm}$ in length and $1.5 \mathrm{~mm}$ diameter in specimen with $14 \mathrm{~cm}$ mantle length. It runs from the buccal cavity and enters the crop on its right side approximately one third of the way from its anterior end. Histologically, the oesophagus has an outer connective tissue layer, supplied with nerves and blood vessels. This is followed by a musculature formed of an outer thick circular layer, and an inner thin longitudinal muscle layer (Fig. 5). The lining epithelium consists of columuar cells, with central oval nuclei and finely fibrillar cytoplasm. These cells secrete the cuticle which covers them throughout the oesophagus. The junction between the oesophagus and crop has a sphincter-like appearance, with over 1-2 mm thickening of the circular muscle layer.

The crop is a large sac that extends to form a pocket inside the mantle cavity. It is an elongated tube with a broad anterior end in starved animals. In newly fed animals, the crop lies at an acute angle to the oesophagus and this helps prevent the reflux of food into the oesophagus. Histologically, the crop is enclosed by a muscular capsule, which consists of an outer circular muscle layer, an intermediate longitudinal muscle layer and an inner thin layer of circular muscle fibres. The inner lining epitheliums is formed of tall columnar cells, with basal oval nuclei, and secrete a thick cuticle layer, which is relatively thicker than that of the oesophagus. (Fig. 6).

The stomach is a muscular sac, lying on the right side of the animal There is no sphincter muscle in the junction between the crop and stomach and thus food may freely cross from one region to the other. The entire stomach is lined with cuticle, which is relatively thin except in the region of the grinding muscle which encircles the stomach transversely. Histologically, the stomach has an outer connective tissue layer supplied with blood vessels and nerves. The musculature of the stomach consists of two thick circular muscle layers, enclosing between them a thin layer of irregular longitudinal fibres. The lining epithelium of the stomach is formed of columnar cells, with fibrillar cytoplasm and basal oval nuclei. These cells secrete an outer thick layer of cuticle which is connected to their outer free border by connective tissue fibres, forming the so-called formative layer (Fig. 7).

Analysis of stomach contents of different specimens of $O$. vulgaris shows that the major food is crustacean animals and fishes but this for small octopuses, while the large octopuses, with higher dorsal mantle length, feed manly on fishes.

The caecum is a coiled organ that lies below the stomach. It has internal leaflet like folds with various sizes which act to increase its surface area. The common duct of the digestive gland opens into the caecum (Fig. 1). Histologically, the caecum is surrounded by an outer sheath of connective tissue that contains nerves and blood vessels. The musculature of the caecum is formed of outer longitudinal and inner circular muscle fibers. The lining epithelium is found in the form of primary leafletlike folds, from which secondary folds are attached (Fig. 8). The epithelium of all folds has ciliated columnar cells with faintly granular cytoplasm and basal oval nuclei. Few secretory cells are found scattered among the ciliated ones (Fig. 9).

The intestine is a long tube, measuring $21 \mathrm{~mm}$ in length and $3 \mathrm{~mm}$ in diameter in specimen with $14 \mathrm{~cm}$ mantle length. It extends from the posterior end of caecum to the rectum. Histologically, the intestine is surrounded by an outer connective tissue layer that is supplied with nerves and blood vessels. This is followed by circular and longitudinal muscle layers. The lining epithelium is extended in the from of longitudinal folds. Each fold has tall columnar cells with granular cytoplasm and basal oval nuclei. These columnar cells enclosed between them few mucous cells which stain faintly red with toluidine blue (Fig. 10). 


\section{Waheed M Emam et al.}

The rectum is a short tube, about $12 \mathrm{~mm}$ in length and $4 \mathrm{~mm}$ in daimeter. There is no external boundary between rectum and intestine. However, internally, the longitudinal folds of the intestine are not found in the rectum. An anal sphincter is found in posterior part of the rectum. No openings for the ink sac or any anal papillae occur around the anal opening. Histologically, the rectum has an inner lining epithelium formed of short non ciliated columnar cells with basal oval nuclei and their free borders are covered with a very thin cuticle (Fig. 11).

The anterior salivary glands are small in size, located at the base of the buccal mass (Fig. 1). Two short ducts extend from them and unite together into a common duct which opens directly into the buccal cavity. Histologically, the anterior salivary glands consist of a number of tubular and tubulo-acinar units bound together with connective tissue. Each tubule is lined with two types of secretory cells (Fig. 13). These cells are columnar in shape with basal nuclei that have conspicuous nucleoli. The secretory granules in the first type are densely distributed allover the cytoplasm and were deeply stained with haematoxylin-eosin as compared with the second one (Fig. 12). The first type of secretory cells is fewer in number than the second one.

The posterior salivary glands are larger than the anterior ones and lie on the anterior part of the digestive gland (Fig. 1). Each leads by a single duct that extends between the supra-and suboesophageal lobes to the buccal cavity. Histologically, Each gland consists of tubular and tubulo-acinar elements like the anterior salivary glands. Their secretory cells are of two types. The secretory granules of the first type are densely distributed allover the cytoplasm and were deeply stained with haematoxylin-eosin as compared with the second one. Cells of the first type more numerous in the tubules of the posterior salivary glands than those found in the anterior ones (Fig. 13).

The digestive gland is a massive grayish cigar-shaped organ that occupies most of the internal cavity of the body. It consists of two united lobes that are enclosed by an outer sheath of connective tissue. Two ducts arise from the posterior end of the digestive gland and unite in a common duct which opens into the caecum (Fig. 1). In cross section, the digestive gland appears to be formed of round-oval tubules that are bound together by a thin strand of connective tissue. The lining epithelium of these tubules is formed of two types of cells. Big vaculated small triangular ones. The former are elongated in shape and has a narrow base resting on the basement membrane, and a wide apex with an outer brush like border, reaching the lumen of the tubules. They contain large secretory granules or brown bodies, but often with aggregated small ones. Some of these cells appear in an advanced stage of secretory activity, being nonvacular with broken outer border. The triangular cells are few, small, and found scattered among the big ones, at the base of the epithelium and hardly reach the lumen of the tubules. These cells, have conspicuous rounded nuclei (Fig. 14).

These constitute small wedge-shaped appendages, lying around the two digestive ducts of the liver (Fig. 1). These appendages open into the two digestive ducts by small tubules. Each appendage is formed of a single layer of short columnar epithelial cells with basal rounded nuclei (Fig. 15).

\section{DISCUSSION}

The digestive system in Octopus vulgaris is well developed and resembles that of vertebrate animals ${ }^{(4)}$ (Andrews, 1983). It differs from that of decapod cephalopods like Sepia and Loligo in having a characterized crop for storage of food and the 


\section{Macro and microscopic structure of the digestive system of Octopus vulgaris From Alexandria water on the Mediterranean Sea}

presence of a single digestive gland. The morphology of the jaws and radula of the $O$. vulgaris can be used as taxonomic tool to differentiate between similar and different species of the family Octopodinae.

Wells ${ }^{(5)}$ mentioned that the oesophagus in octopuses widens to form a crop when it reaches the level of the mantle. However, this isn't quite exact. Since the spontaneous contractile activity of the oesophagus and crop was observed to be different in the present living animal just dissected in Lab to obtain its internal organs. Besides, there appears to be no free interchange of fluid between the two organs due to the presence of sphincter muscles as shown in the present results.

In general, the basic plan of organization of the digestive system of Octopus vulgaris has been found to conform with that described in other groups of Octopodidae. Histologically, the structure of the oesophagus, stomach, intestine and rectum of $O$. vulgaris agrees well with the description given by Bidder ${ }^{(6)}$ on European squids, Boucaud-Camou ${ }^{(7)}$ on Sepia officinalis and Emam ${ }^{(7)}$ on S. savignyi.

The toxicity of the two pairs of Salivary glands of $O$. vulgaris was reported by Gennaro et al. ${ }^{(9)}$ and Wells ${ }^{(5)}$. The gross anatomy of the salivary apparatus in $O$. vulgaris from the Catalan Sea, was investigated by Bolye et al. ${ }^{(\mathbf{1 0})}$. Saad and Emam ${ }^{(\mathbf{1 0})}$ studied the toxic potentiality of the anterior and posterior salivary glands of $O$. vulgaris according to the differences in their histology, histochemistry and fine structure of their component cells.

The anterior and posterior salivary glands of $O$. vulgaris were found to consist of tubules, with two types of secretory cells. This is in agreement with Gennaro et $a l^{(\mathbf{8})}$, Saad and Emam ${ }^{(\mathbf{1 1})}$. It is noticeable, that, unlike the situation in other mollusks, the digestive gland in cephalopods seems to produce the large amounts of digestive enzymes necessary for extracellular digestion and is also capable of endocytosis and intracellular digestion. That dual function makes it hard to understand the structure and the cytoplasmic changes in the cell, and may be related to the length of the digestive process ${ }^{(\mathbf{1 2})}$. The complex structure of the digestive cells, which seems in continuous activity, indicates the important metabolic role of the gland. This digestive gland was considered also as a storage organ. The digestive gland of the present samples of $O$. vulgaris includes big cells with brush-like border, basal rounded nuclei and "boules" in the cytoplasm. These cells correspond to the rip-club cells of Bidder ${ }^{(5)}$ on European squids. Moreover, some of the big cells described in the present study are found in an advanced stage of secretory activity, having lost their outer border, and appear without vacuoles. This stage was considered as a third type of cells by Boucher-Rodoni and Mangold ${ }^{(\mathbf{1 3})}$ and as " gray body cells" by Bidder ${ }^{(\mathbf{1 4})}$ for the same species.

Boucher-Rodoni ${ }^{(\mathbf{1 5})}$ indicated that the digestive process begins in stomach and is completed in the caecum. Also she found that absorption takes place in the digestive duct appendages (pancreas) and in the digestive gland, while the undigested particles are evacuated by the intestine where no absorption takes place. Moreover, Boucher-Rodoni ${ }^{(\mathbf{1 6})}$ found changes of proteolytic activity related to the stage of digestion in the digestive gland of Sepia officinalis and Eledone cirrosa. 


\section{REFERENCES}

1-Roper C.F.E.; Sweeney, M.J. and Nauren, C.E. (1984). FAO SPECIES CATALOGUE. CEPHALOPODS OF THE WORLD AN ANNOTATED AND ILLUSTRATED CATALOGUE OF SPECIES OF INTEREST TO FISHERIES. FAO Fisheries Synopsis No. 125, Volume 3.

2- Boyle, P.R. (1983). Eledone cirrhosa. In: P.R. Boyle, ed. Cephalopod Life Cycles. Vol. I, Species Accounts. Academic Press, London. Pp. 365-386.

3- Matus, A. I. (1971). Fine structure of the posterior salivary gland of Eledone cirrosa and Octopus vulgaris. Tissue and Cell, 5(4): 591-601.

4- Andrews, P. and Tansey, E. M. (1983): The digestive tract of Octopus vulgaris: The anatomy, physiology and pharmacology of the upper tract J. Mar. biol. Ass.U.K. 63:109-134.

5- Wells, M. (1978). Octopus: Physiology of an Advanced Invertebrates. Chapman and Hall. London.

6- Bidder, A. M. (1950). The digestive mechanism of the European squid Loligo vulgaris, L. forbesi and Alloteuthis media. Quart. J. Microscop. Sci., 91: 1-43.

7- Boucaud-Camou, E. (1968). Loclisation d'activities amylasiques et proteasquie dens l'appareil digestive de Sepia officinalis, L.C.R. Acad. Sci. Paris, 2699: 2264-2566.

8- Emam, W.M. (1983). Biological studies on some cephalopods common in Egyptian waters, M. Sc. Thesis, Ain Shams Univ., pp: 61-71.

9- Gannaro, J. F. and Breuster, H. B. (1965): The anterior salivary gland of Octopus vulgaris and its mucous secretion. Ann. N. Y. Acad. Sci., 118: 1021-1025.

10- Boyle, P. R. Mangold, K. and Froesch, D. (1979). The organization of beak movement in Octypus. Malcol., 18: 423-430.

11- Saad, A. A. and Emam, W.M. (1998): Studies on the poisonous salivary glands of Octopus vulgaris from the Mediterranean Sea, Proc. Proceedings of the Egyptian Academy of Sciences, 48: 81-93.

12- Boucaud-Camou, E. (1980). Fine structure and function of the digestive cell of Sepia officinalis. J. Zool. Lond., 191: 89-105.

13- Boucher-Rodoni, R. and Mangold. K. (1977). Experimental study of digestion in Octopus vulgaris (Cephalopoda: Octapoda). J|. Zool., 183:5050-515.

14- Bidder, A. M. (1976): Sepia afficinalis. New names for old: the cephalopod "Mid-gut gland" J. Zool. London, 180: 441-443.

15- Boucher-Rodoni, R. (1977): Experimented study of digestion Octopus vulgaris (cephalopoda: Octopoda). J. Zool. Lond., 183: 505-515.

16- Boucher-Rodoni, R. (1982): La glande des cephalopodes. Can. Biol. Mar., 23: 299-318. 

vulgaris From Alexandria water on the Mediterranean Sea

\section{List of abbreviations}

a.s.gl. anterior salivary gland

an anus

b.b. brown body

b.c. big cell

b.m. buccal mass

ca caecum

cil. col. c. ciliated columnar cell.

co.l.c. columnar cell

cro crop.

cu. cuticle

dg. gl. digestive gland

dg.ap. digestive duct appendages

int. intestine

j. jaw

l.b.p lateral buccal palp.

l.mand.m. lateral mandibular muscle

lu. lumen

m.c. mucous cell

n. nucleus

oes. oesophagus

p.aci. pancreatic acinus

p.s.gl. posterior salivary gland

p.s.gl.d posterior salivary gland duct.

pr.l.ca. 1ry leaflet-like folds of caecum

ra. radula

ra. re.m. radular retractor muscle

ra. sup. radular support

rec. rectum

sb. mand. gl. submandibular gland.

sec. c. secretory cell

st. stomach

sup.mand.m. superior mandibular muscle

tri.c. triangular cell

up. bk. upper beak

v. vacuole 
Waheed M Emam et al.

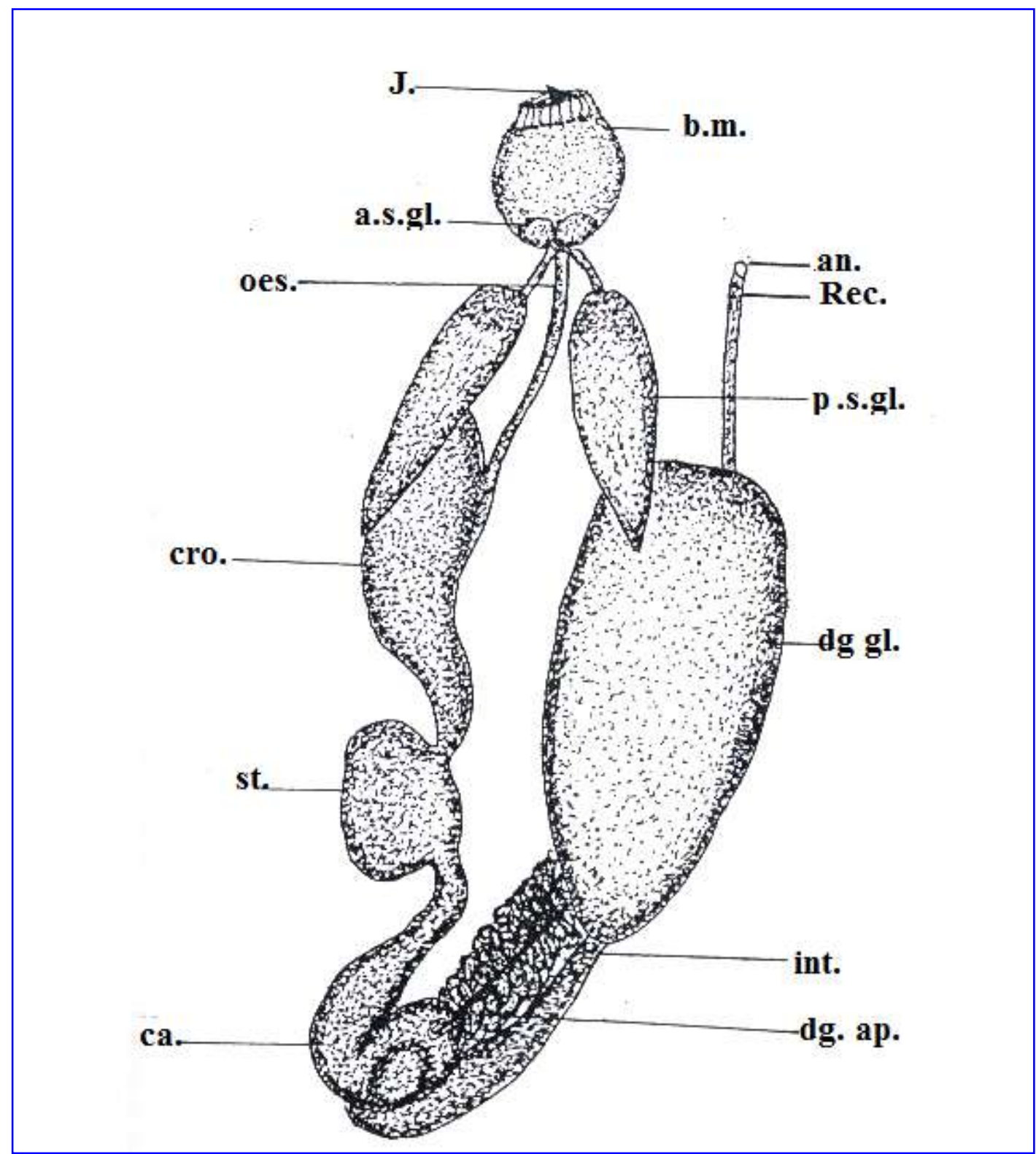

Fig. (1): Camera lucida drawing of the spread digestive system of $O$. vulgaris to show its different parts. X8 
Macro and microscopic structure of the digestive system of Octopus vulgaris From Alexandria water on the Mediterranean Sea

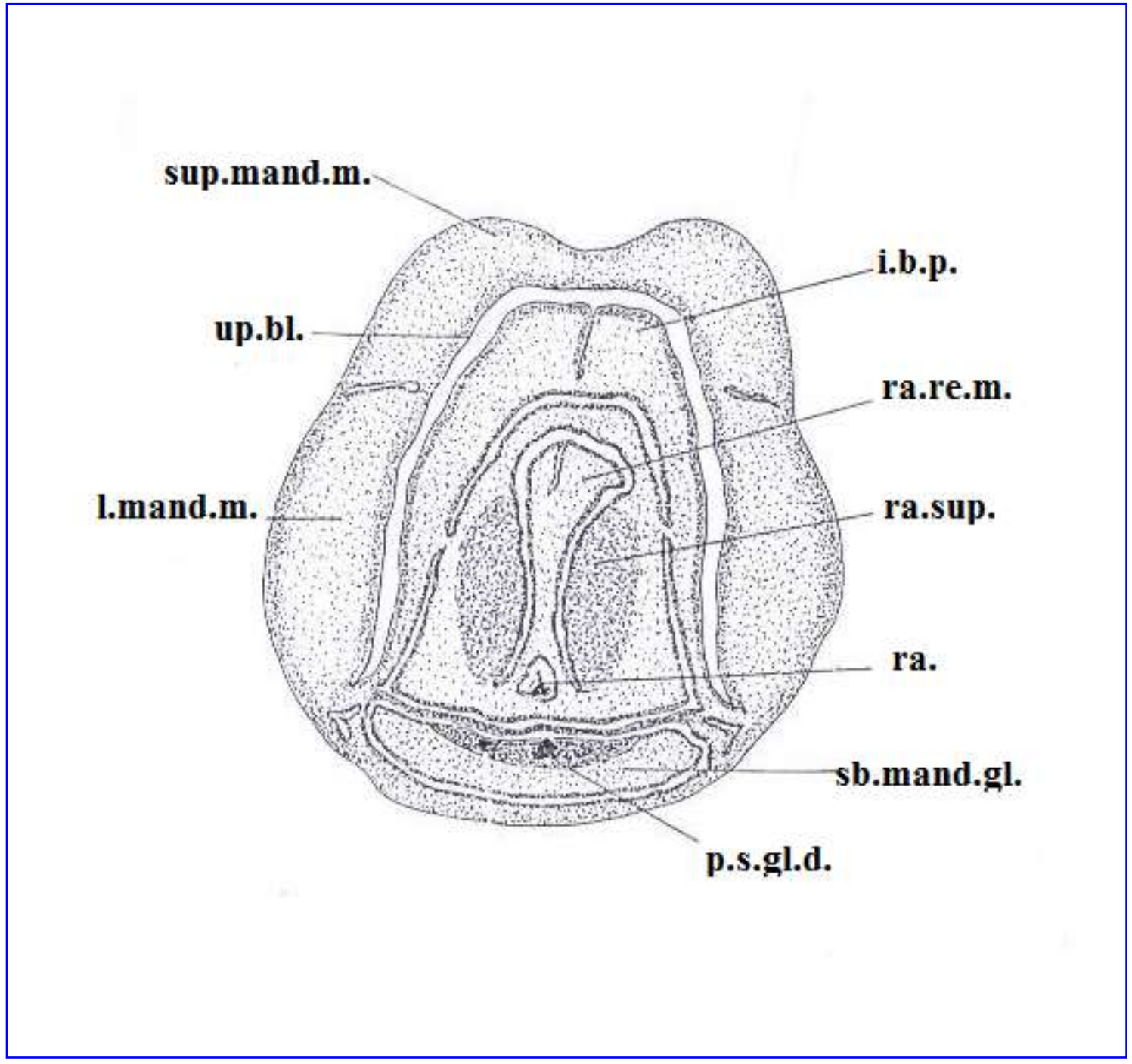

Fig. (2): Camera lucida drawing of T.S. of buccal mass to show the structure of its different parts. X2.5 
36

Waheed M Exam et al.

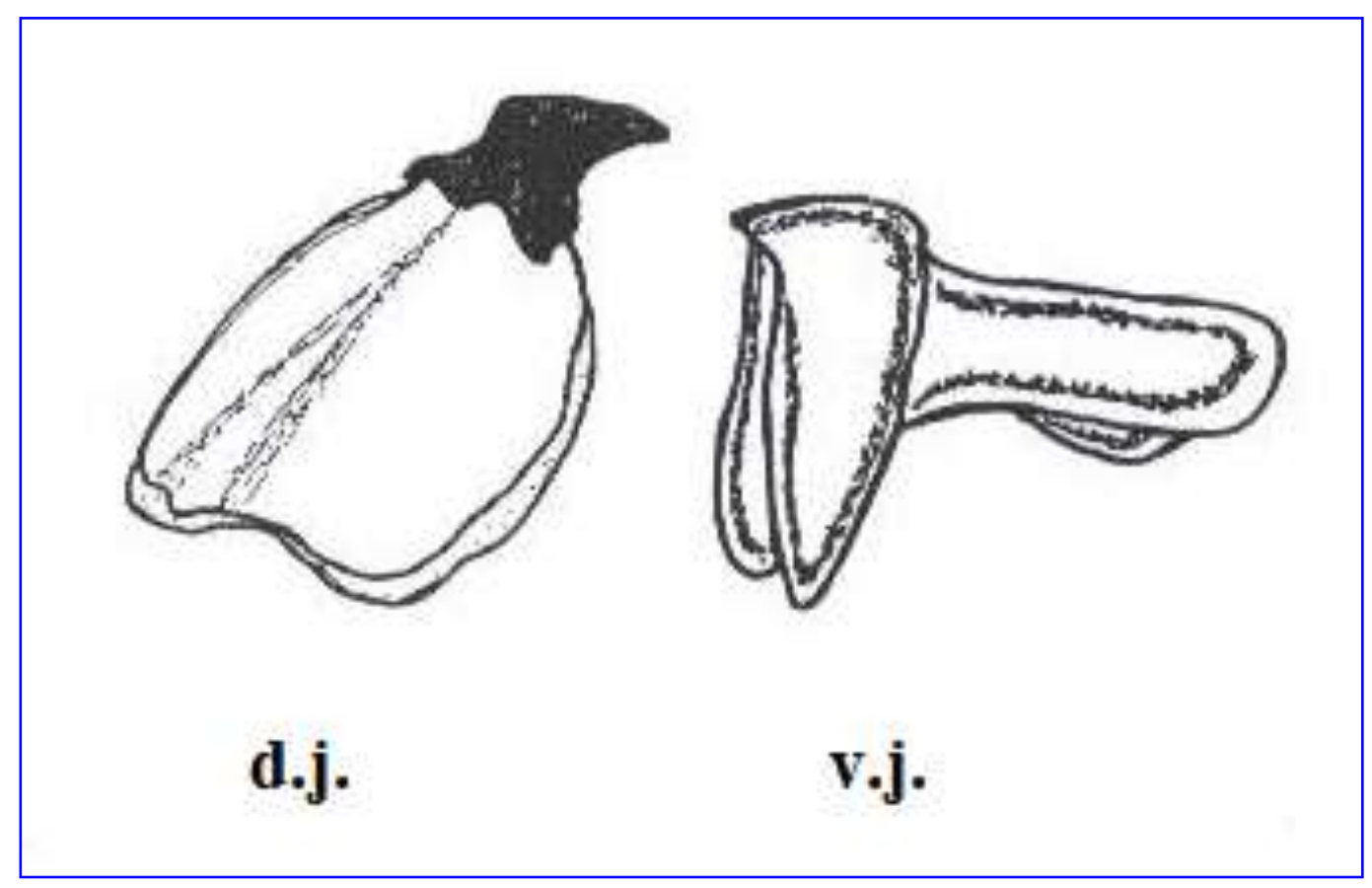

Fig. (3): Camera lucia drawing of dorsal and ventral jaws.s X2.5

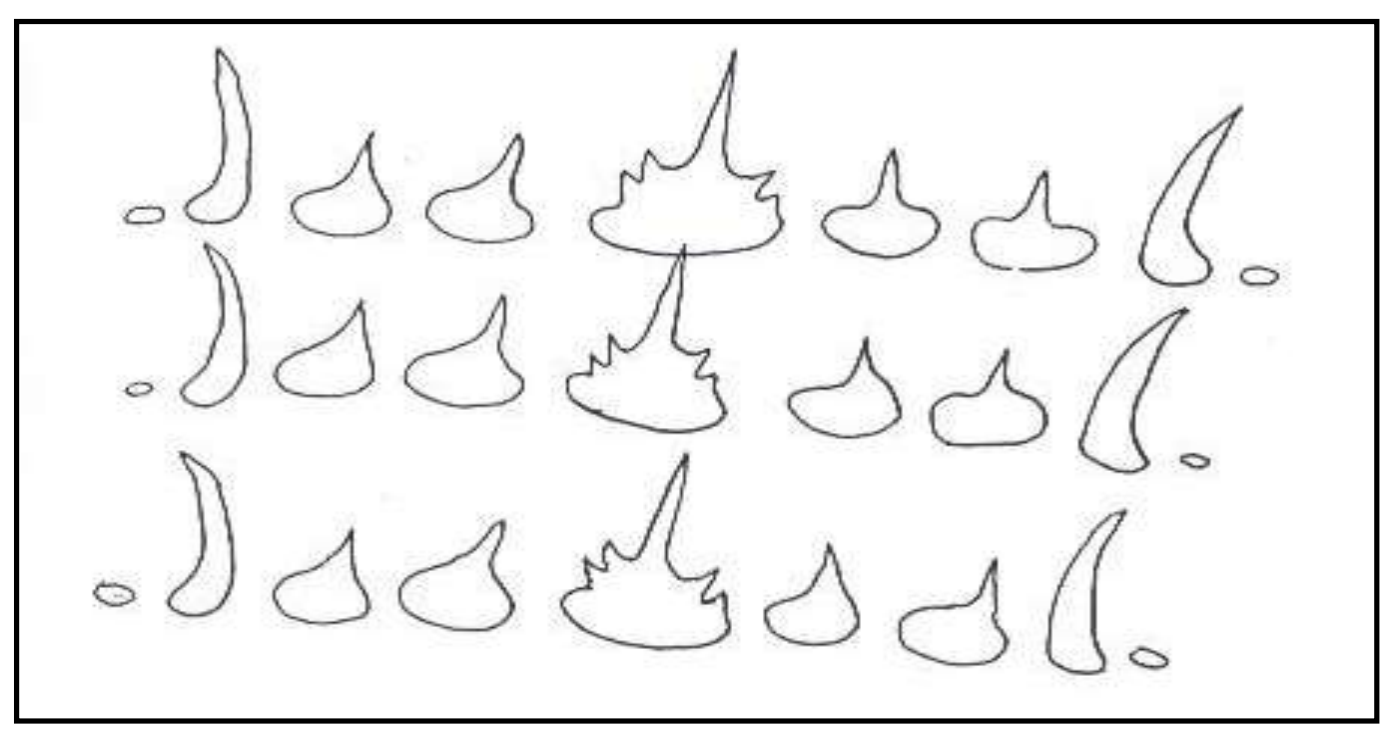

Fig. (4): Camera lucida drawing of the 3 transverse rows of radular teeth. X100 
Macro and microscopic structure of the digestive system of Octopus vulgaris From Alexandria water on the Mediterranean Sea

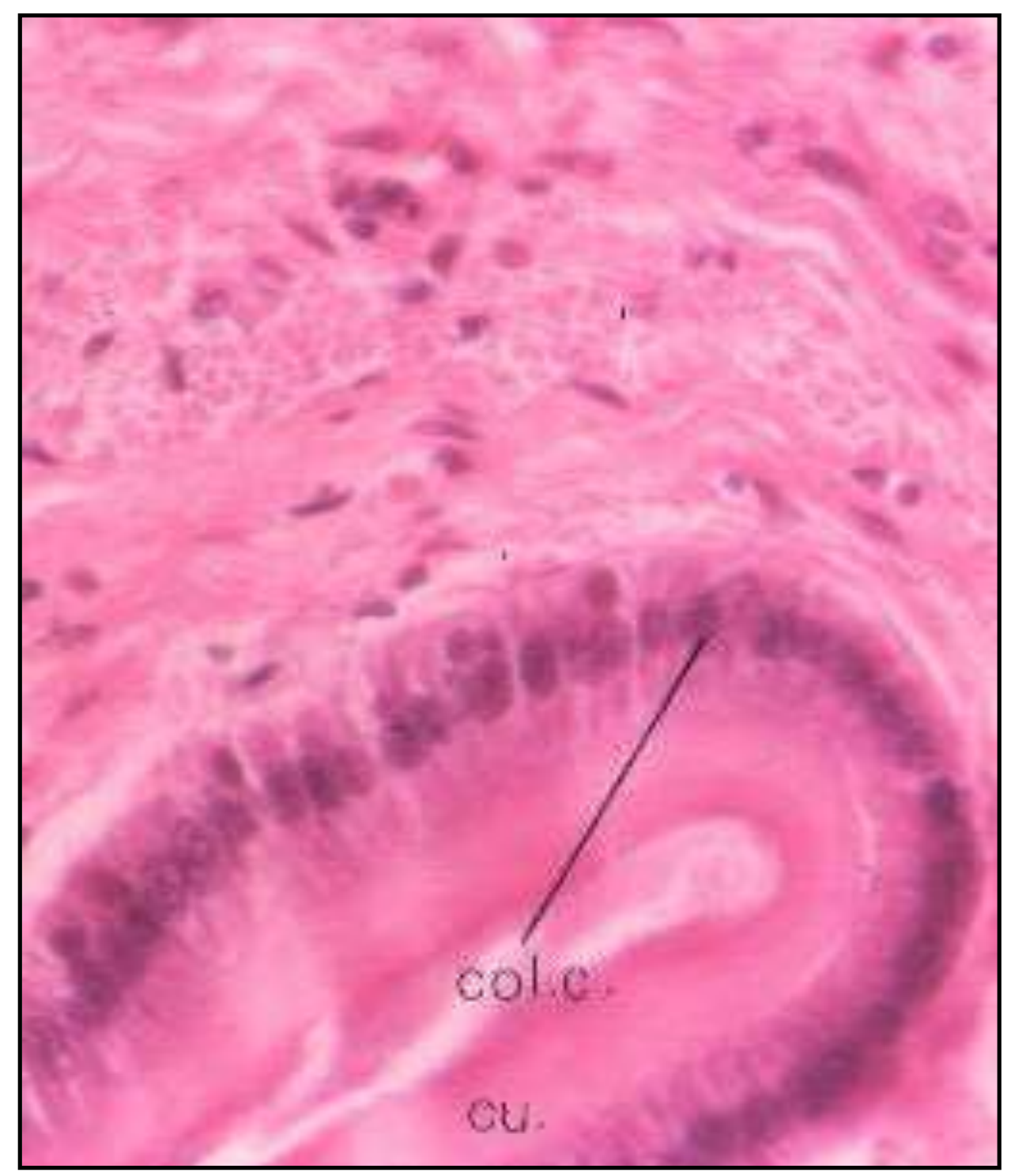

Fig. (5): Enlarged part of T.S. of the linin g epithelium of the oesophagus of $O$. vulgaris stained with Hx.E. X 1200. 
Waheed M Emam et al.

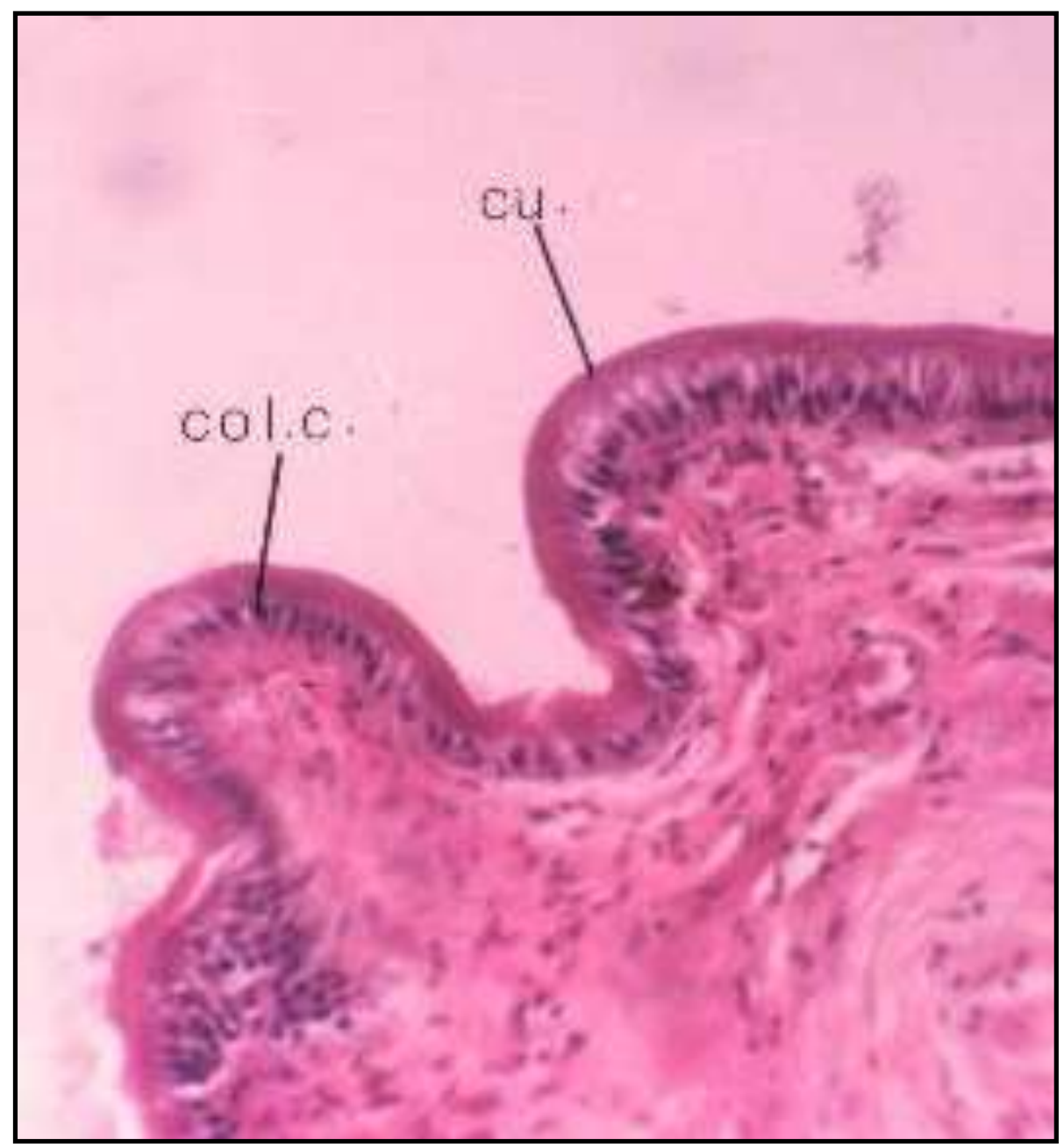

Fig. (6): Enlarged part of the lining epithelium of the crop of $O$. vulgaris, stained with Hx.E. X300. 
Macro and microscopic structure of the digestive system of Octopus vulgaris From Alexandria water on the Mediterranean Sea

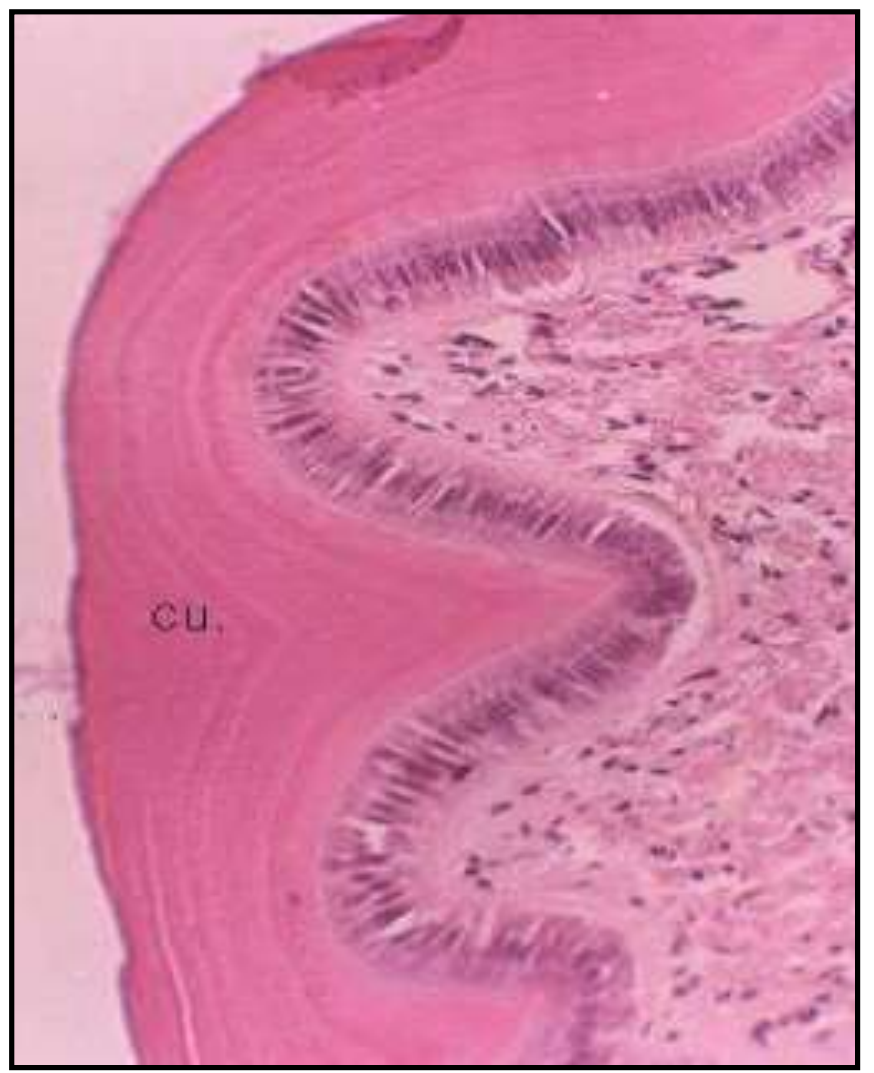

Fig. (7): Enlarged part of the lining epithelium of the stomach of $O$. vulgaris stained with Hx.E.X1200.

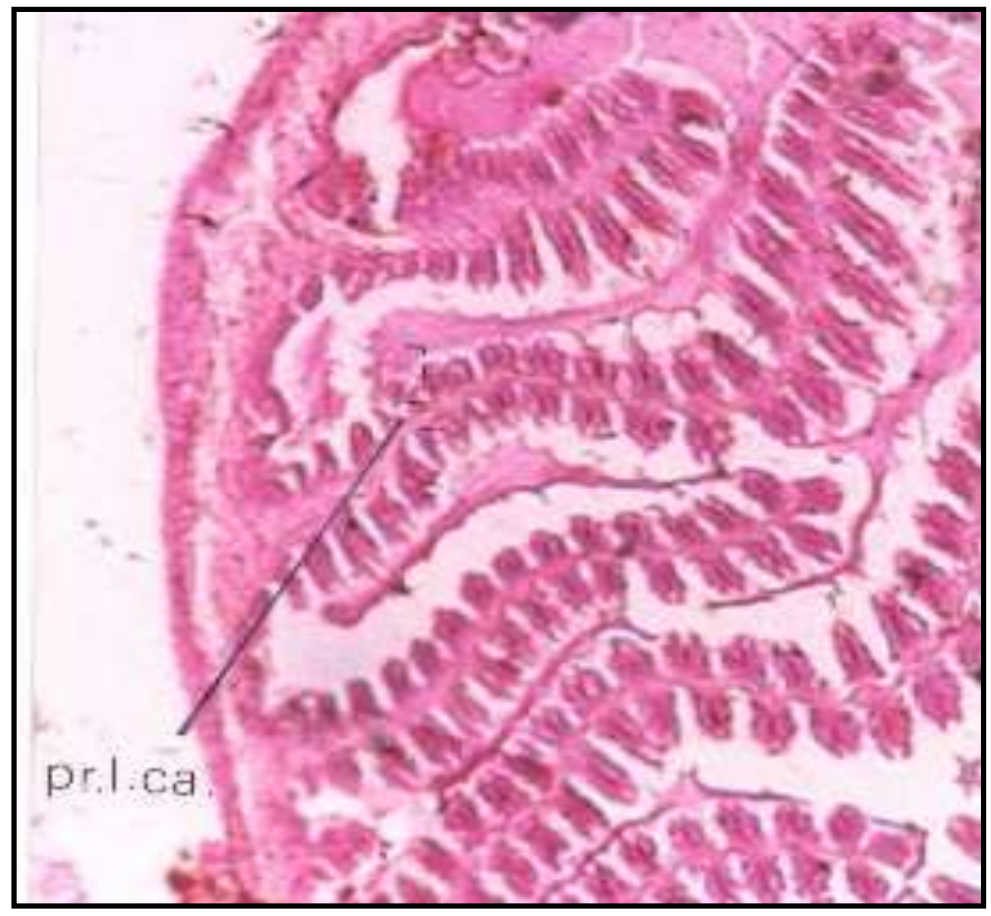

Fig. (8): T.S of part of caecum of $O$. vulgaris stained with Hx.E. X120. 
Waheed M Emam et al.

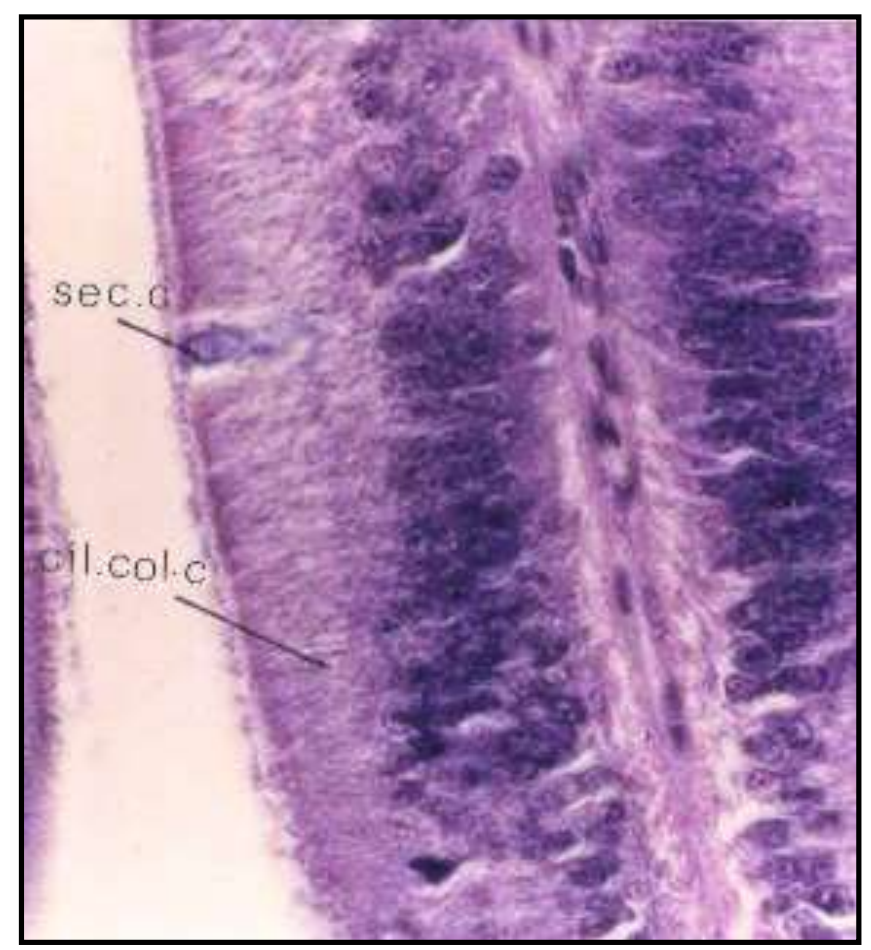

Fig. (9): Enlarged part of Fig. (8). X1200.

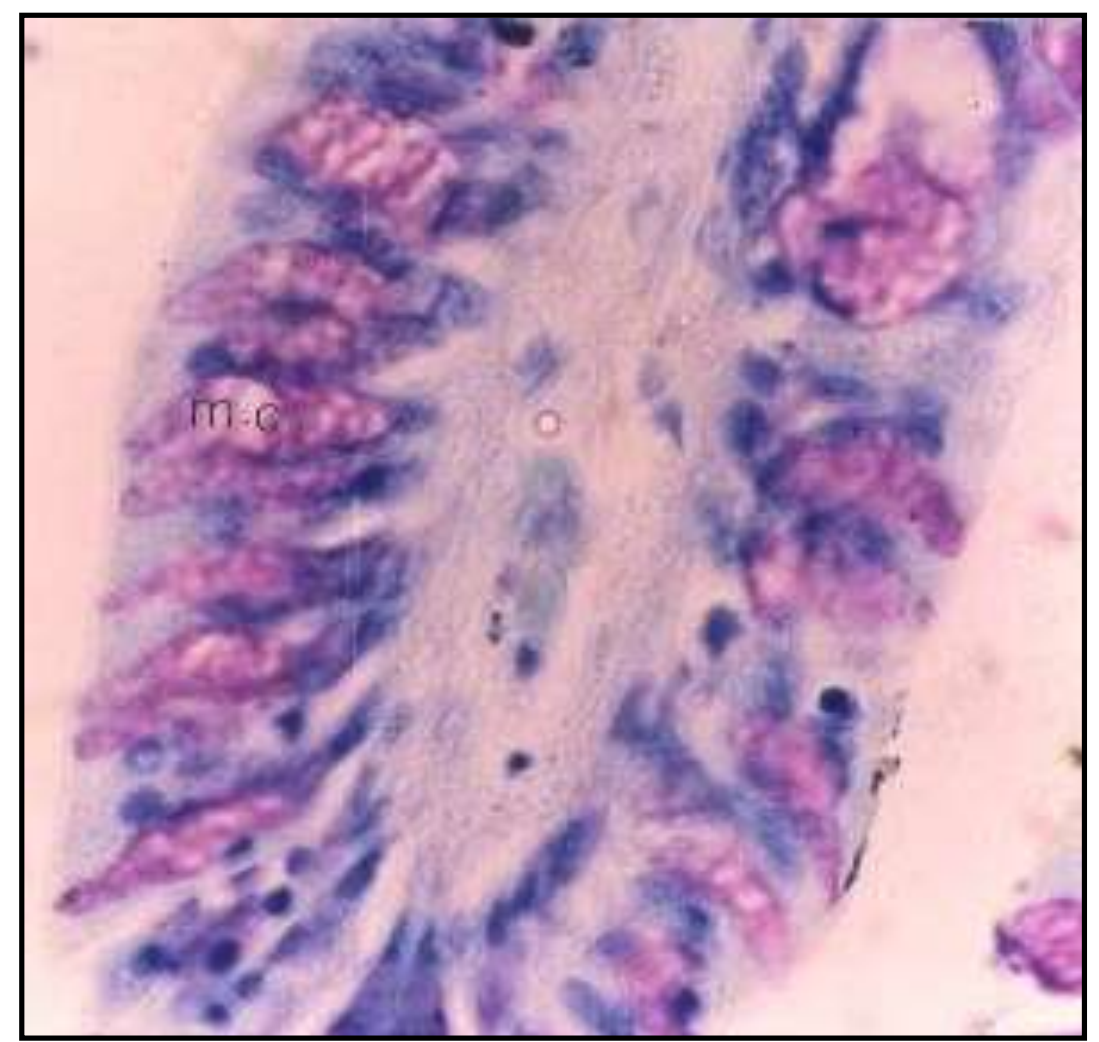

Fig. (10): Enlarged part of the lining epithelium of the intestine, stained with toluidine blue showing the secrotory cells X1200. 
Macro and microscopic structure of the digestive system of Octopus vulgaris From Alexandria water on the Mediterranean Sea

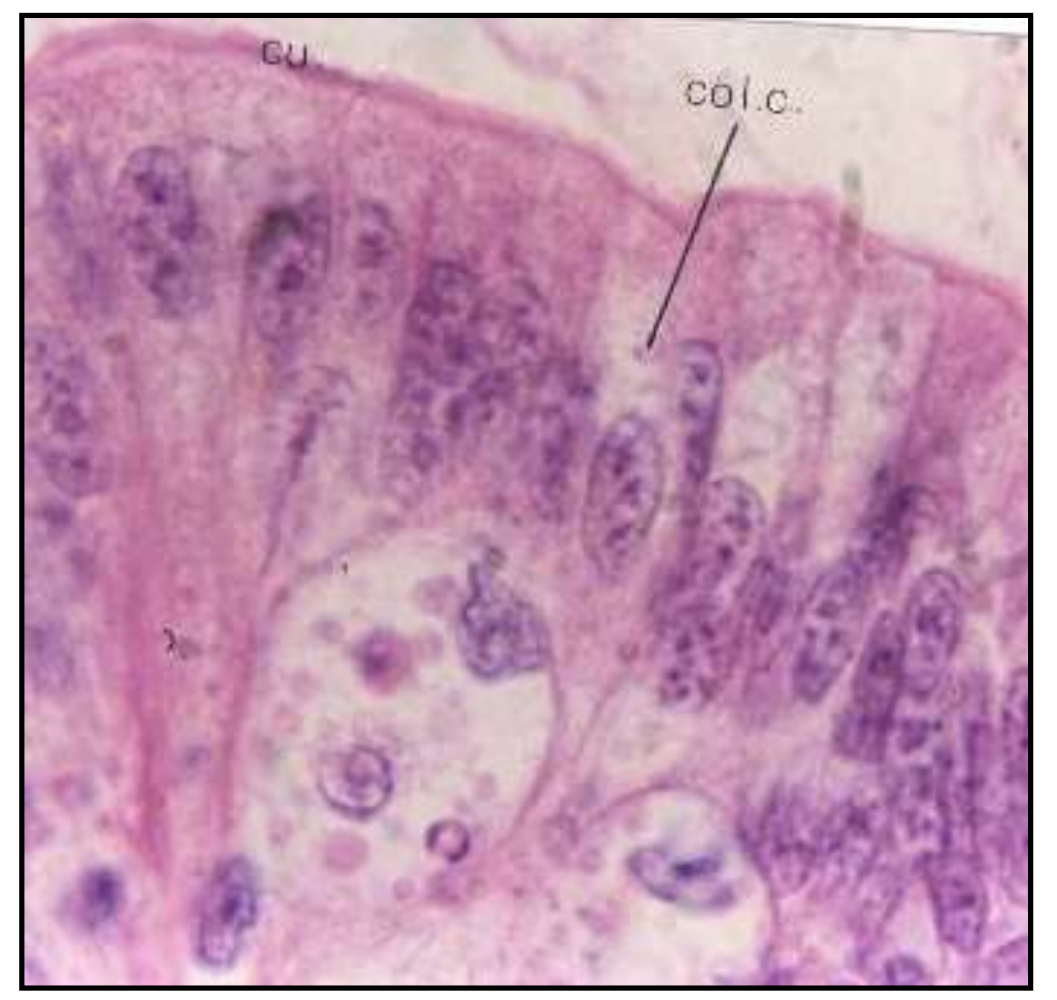

Fig. (11) T.S of the rectum, showing the covering cuticle Hx.E stain X1200. 
Waheed M Emam et al.

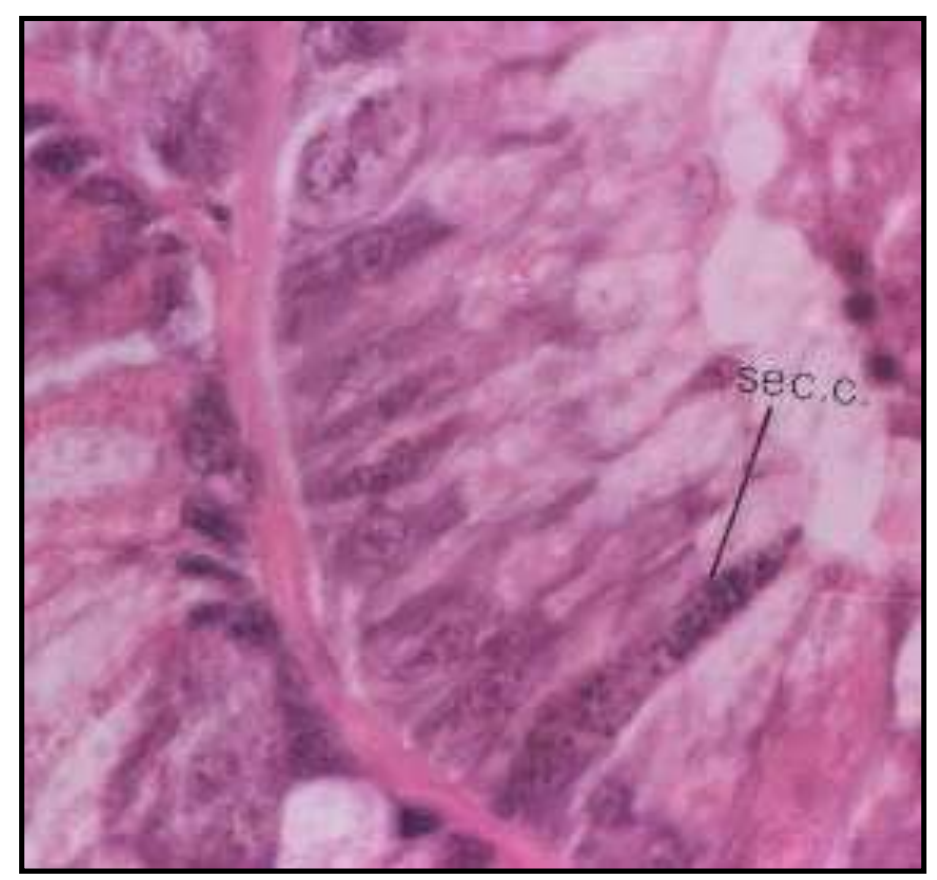

Fig. (12): T.S of the anterior salivary gland of $O$. vulgaris, showing secretory cells. Hx.E. X1200.

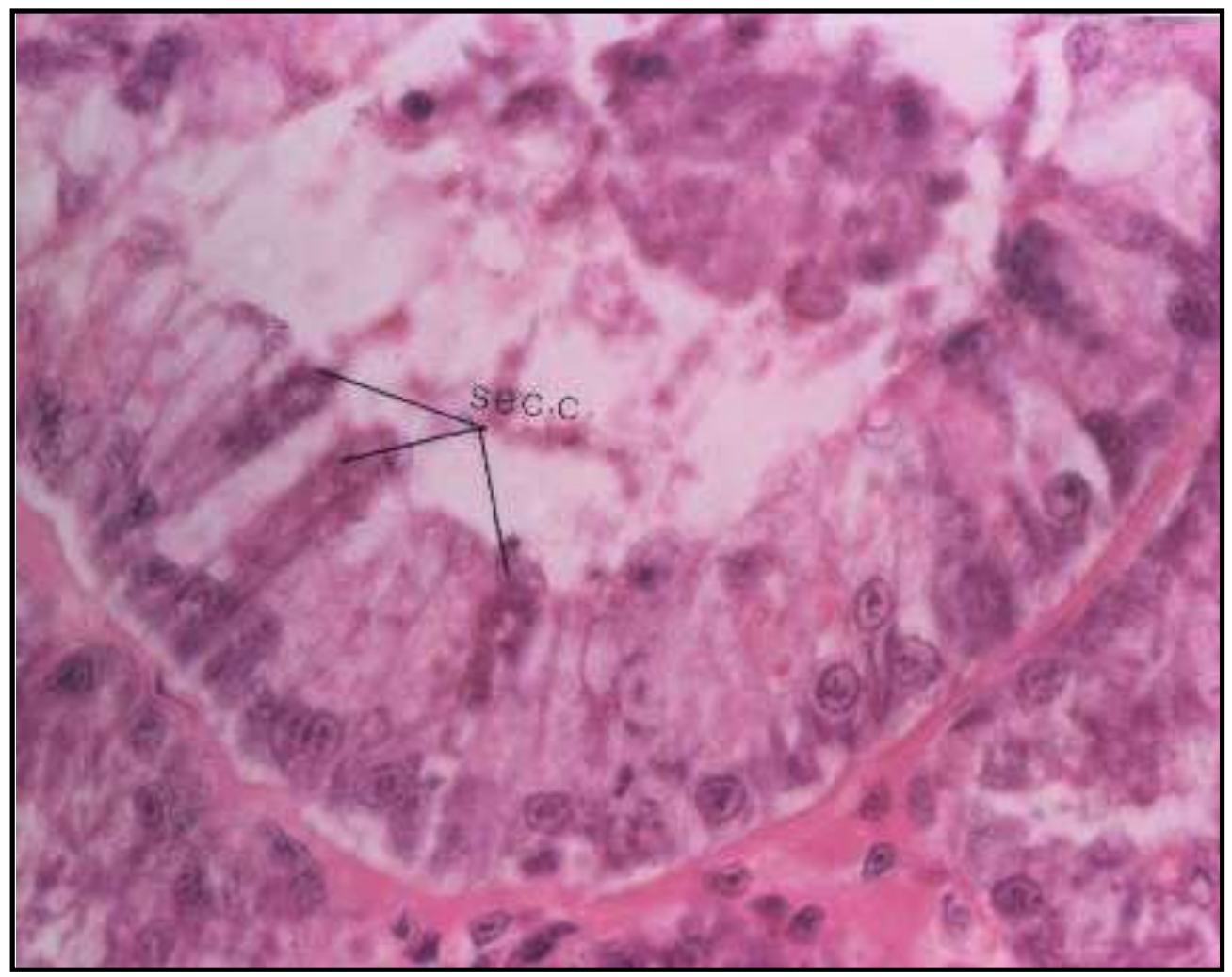

Fig. (13): T.S of the posterior salivary gland of $O$. vulgaris, showing secretory cells. Hx.E. X1200. 
Macro and microscopic structure of the digestive system of Octopus vulgaris From Alexandria water on the Mediterranean Sea

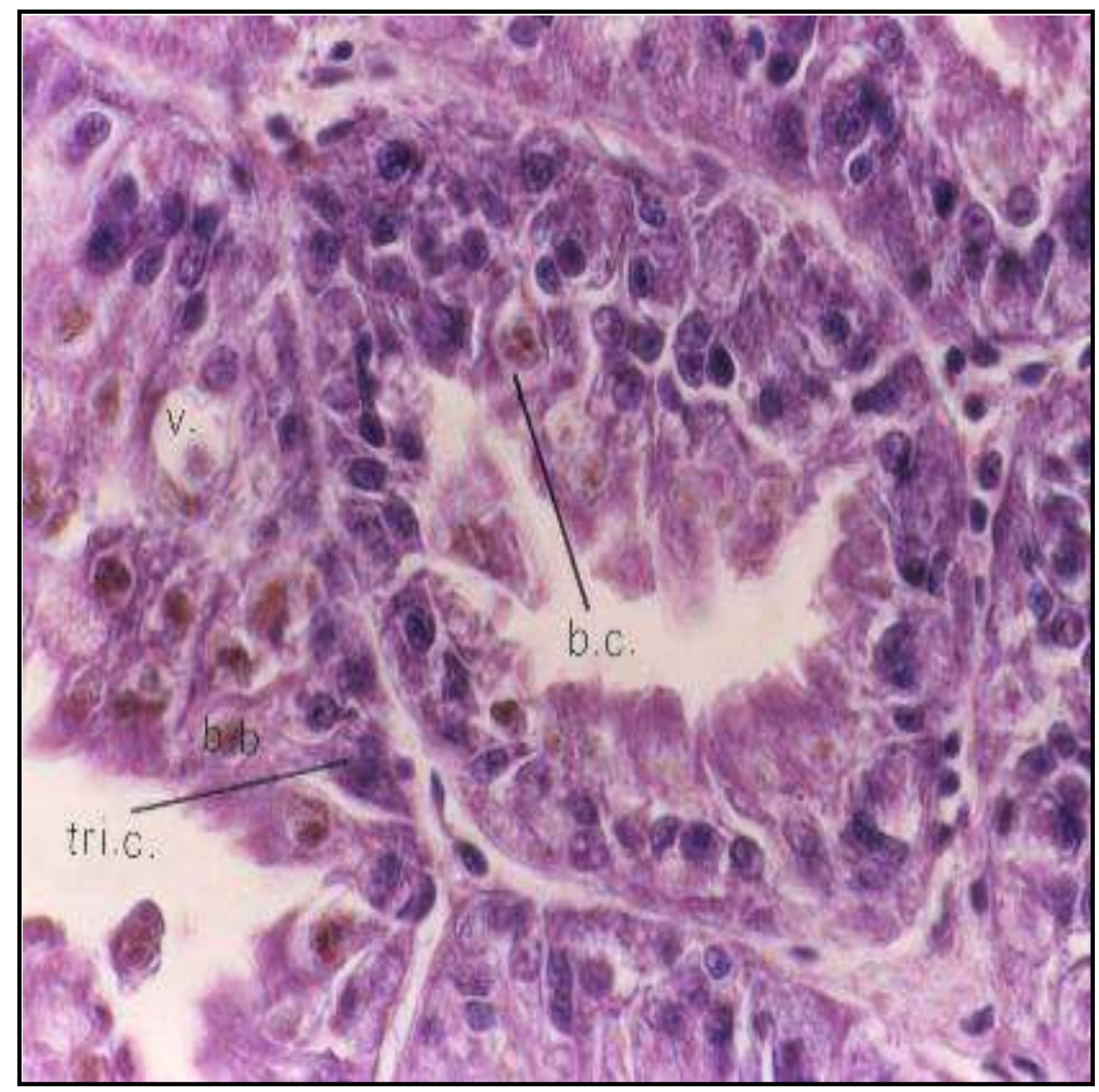

Fig. (14): T.S of the digestive gland of $O$. vulgaris, Hx.E. X1200. 
Waheed M Emam et al.

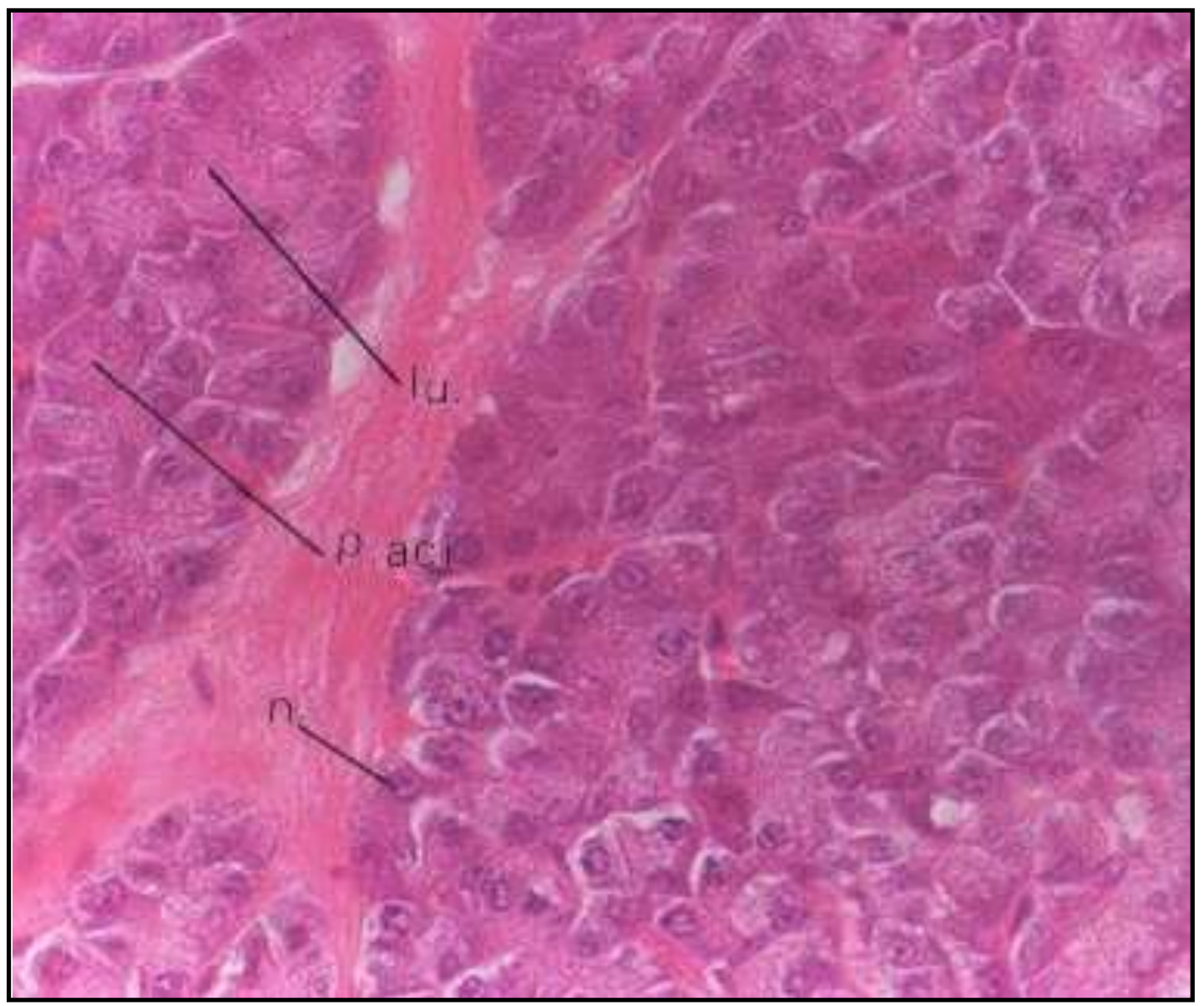

Fig. (15): T.S. of the digestive duct appendages of $O$. vulgaris, Hx.E. X1200. 


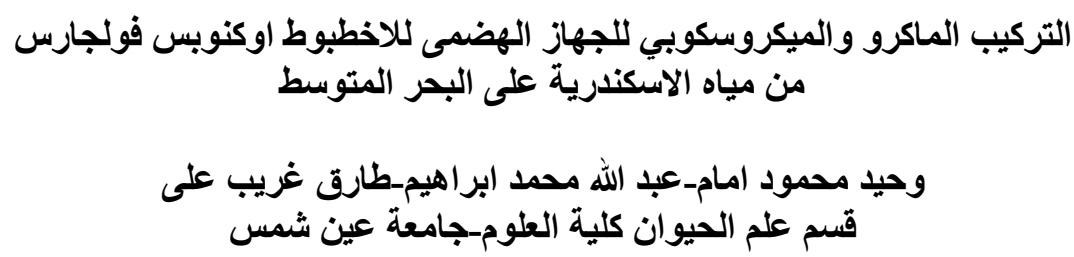

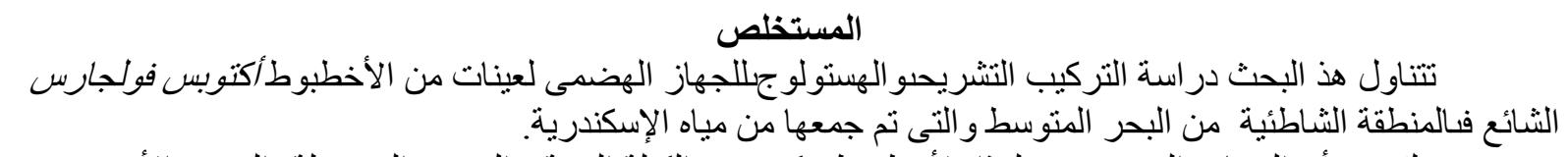

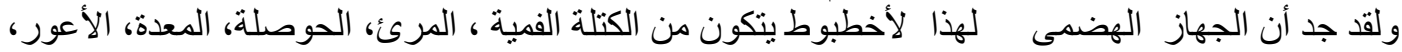

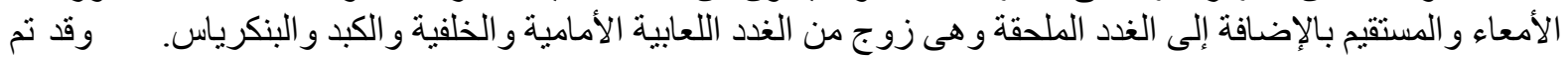

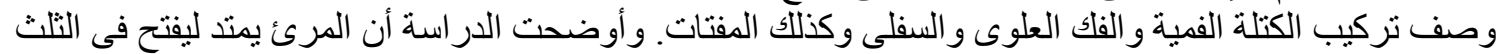

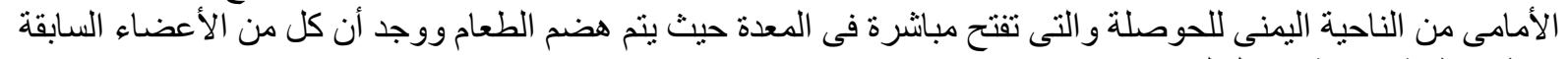

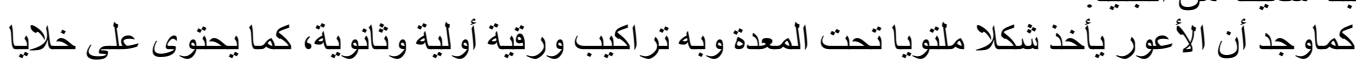

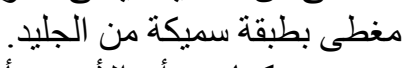

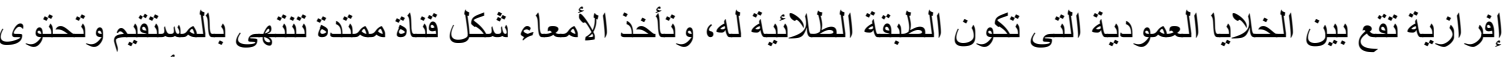

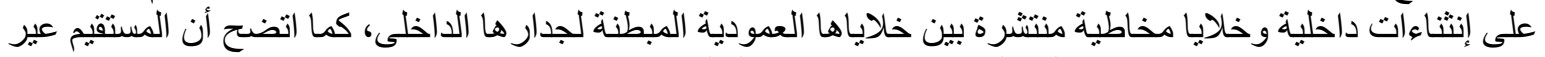

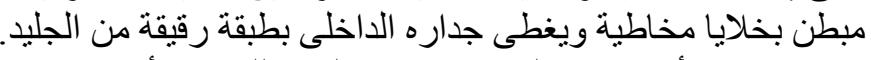

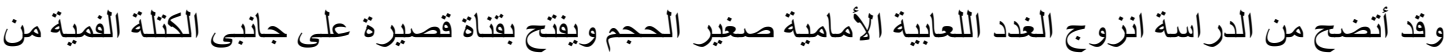

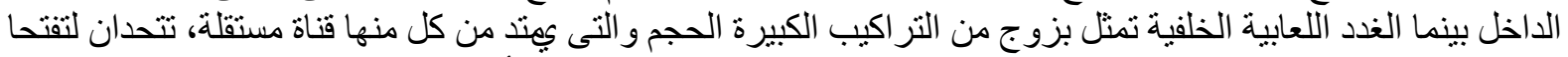

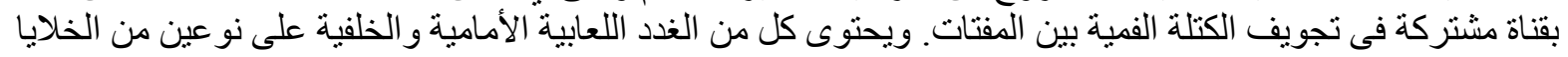
الإفرازية.

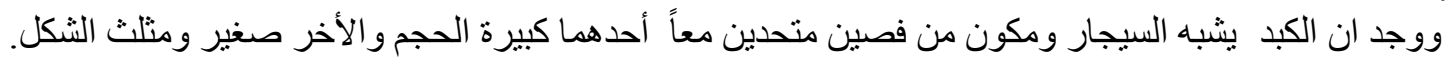

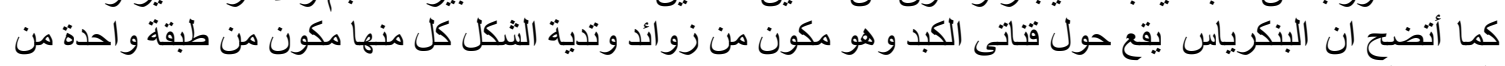
الخلايا العمودية. 